\title{
DRILLING OF CARBON FIBRE REINFORCED POLYMER MATERIALS - A REVIEW
}

\author{
BELLAM VENKATESH ${ }^{1} \&$ RAHUL SINGH SIKARWAR ${ }^{2}$ \\ ${ }^{1}$ Department of Mechanical Engineering, CMR Institute of Technology, Hyderabad, Telangana, India \\ ${ }^{2}$ School of Mechanical Engineering, Vellore Institute of Technology, Vellore, Tamil Nadu, India
}

\begin{abstract}
Drilling is a secondary manufacturing process used for the finishing of the parts done in the primary manufacturing. For drilling of traditional materials, there are several techniques available to attain the objective of good circularity of the hole without any damage. Drilling of the CFRP material is difficult, because of its anisotropic and non-homogeneous in nature. Carbon fibre reinforced materials extensively used in the aerospace industries, because of its specific properties in strength and stiffness. Hence, the drilling of CFRP requires a lot of research for using in the aerospace industry. The principal aim of this paper is to present an extensive literature report in the drilling of CFRP and that includes the studies on different input variables such as machining parameters (speed, feed and drill point angle) and drill biton the drilling induced damages. Also, the study focuses effects of input variables on delamination and hole circularity and induced thrust force and torque.
\end{abstract}

KEYWORDS: CFRP, Delamination, Drilling, Thrust Force \& Surface Roughness

Received: Jan 14, 2018; Accepted: Feb 05, 2018; Published: Feb 26, 2018; Paper Id.: IJMPERDAPR201817

\section{INTRODUCTION}

Carbon fibre reinforced plastic (CFRP) composites have been widely used in engineering application such as automotive, aircraft and manufacture of spaceships and sea vehicles' industries due to their significant advantages over other materials. They provide high specific strength/stiffness, superior corrosion resistance, light weight construction, low thermal conductivity, high fatigue strength, ability to char and resistance to chemical and microbiological attacks [1,2]. As a result, advanced composite materials make about 50\% of the structural weight of Boeing 787 and Airbus A350XWB. Generally, parts made of composites produced to a near-net shape, but additional machining operations are often required to facilitate component assembly [3-4]. Among those operations, drilling is one of the most common. It is usually required to allow the application of screws and rivets in the assembly of parts. This can be carried out with conventional tools and machining equipment, sometimes with some adaptations [5]. However, due to the heterogeneity, anisotropy, and high abrasiveness of fibres, drilling operation can lead to different kinds of damages [6]. It exhibits considerable problems in a drilling process such as delamination, fibre pull-out, hole shrinkage, spalling, fuzzing and thermal degradation [7]. Among the defects caused by drilling, delamination around the drill hole site appears to be the most critical, which can result in a lowering of bearing strength and can be detrimental to durability by reducing the in service life under fatigue loads [8]. Delamination can often become a limiting factor in the use of FRPs for structural applications. Therefore, addressing how to improve the quality of the holes in the drilling of FRPs is imperative [9]. As an example, over a 100000 holes are required for small single engine aircraft, and in a large transport aircraft millions of holes are drilled. The delamination damage is associated with 50-60\% of all parts rejections during final assembly of an aircraft [10]. Many references have shown that the thrust force is also major factor responsible for drilling-induced delamination and it mainly depends on drill materials, drill geometry and feed rate [11]. 
In addition to delamination, sub-surface deformation is another important drilling induced damage while composite machining, Interfacial deboning, matrix deformation, fiber pullouts, matrix crazing, cracking, hole shrinkage and spalling are few examples of sub-surface deformations [12]. So, in order to improve the product performance and structural integrity of machined holes, the material defects such as sub- surface deformation and delamination has to be trimmed-down by proper selection of cutting parameters, tool geometries, tool types and cutting conditions [13]. Spalling and fuzzing are considered as the major exit damage mechanisms during drilling of FRP composite laminates and these damages increase with an increase in feed rate and decrease in spindle speed. Spalling at hole exit is usually a severe damage and it is bigger for UD-CFRP laminate as compared to multi-directional CFRP laminate under the same drilling conditions [14].

The increasing popularity of carbon composites in the industry and the constant need to maximize productivity has led researchers to look at methods of optimizing the drilling process. Therefore, the present work provides a detailed review of drilling on CFRP composite

\section{DRILLING OPERATION}

Although several non-traditional machining operations such as laser machining, water-jet machining and electrical discharge machining have been developed for application to hole-making of composite laminates, mechanical drilling operations Using conventional or special drill bits are the primary applications for composite laminates [3]. The factors such as cutting parameters, tool geometries, tool materials, thrust force and torque greatly influence the drilling of CFRP laminates and quality of the drilled hole [15].

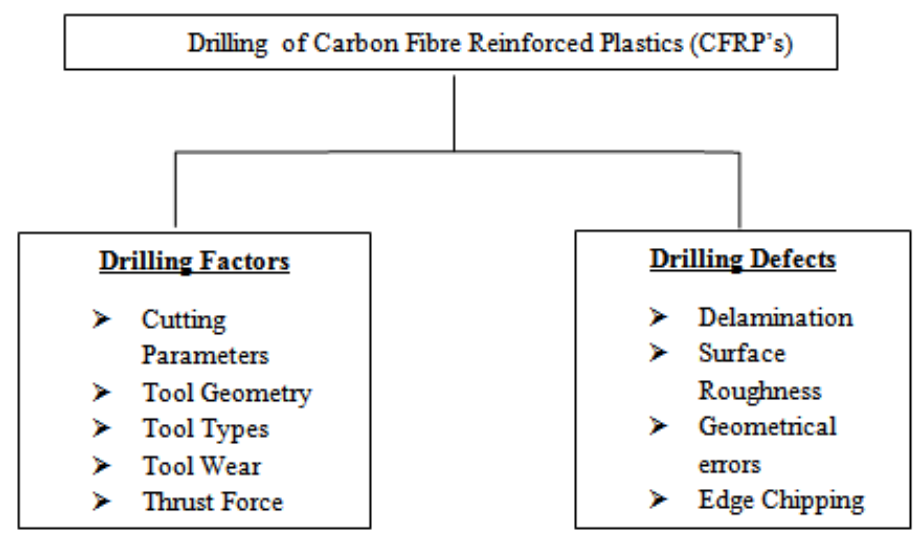

Figure 1: Research Area in Drilling CFRP Composite

\section{Delamination Mechanism in CFRP Composite}

Delamination is the most common and serious damage caused during drilling of composite materials and considered as the limiting factor in the drilling process of FRP [16]. It is defined as the separation of adjacent composite plies and characterized by the formation of inter laminar cracks in the material. This damage occurs during drilling, on the hole entrance (peel-up delamination) as well as at the hole exit side (push-down delamination) as illustrated in Figure. 3. Peel-up delamination (Figure 3. a) is a consequence of cutting force pushing the abraded and cut material to the flat surface. Push - down delamination (Figure 3. b) is a damage that occurs in interlaminar regions, so it depends not only on the fibre nature, but also on the resin type properties. This damage is the consequence of the compressive thrust force that 
the drill bit edge always exerts on the uncut laminate plies [17]. Delamination (Fd) can be defined as the ratio of maximum diameter to the nominal diameter of the hole as present in the below equation [18].

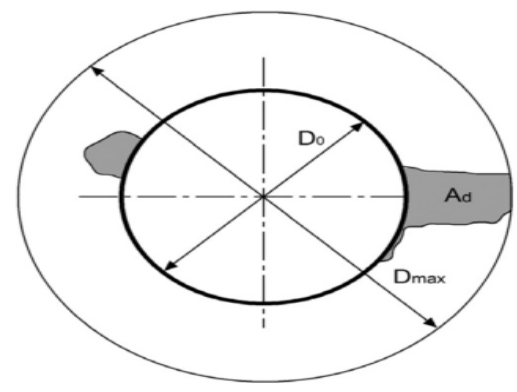

Figure 2: Schematic Representation of the Geometric Parameters [6]

$$
\mathbf{F}_{\mathbf{d}}=\frac{D_{\max }}{D_{o}}
$$

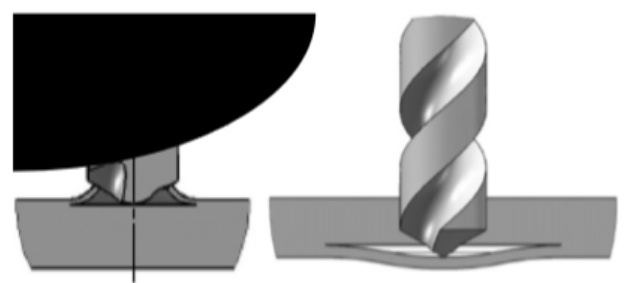

(a)

(b)

Figure 3: Delamination Mechanisms: A) Peel - Up Delamination at Entrance

B) Push - Down Delamination At Exit [11]

Where $\mathrm{D}_{\max }$ denotes the maximum diameter of the damaged hole,

$\mathrm{D}_{0}$ denotes the nominal diameter of the hole.

\section{Effect of Drilling Factors on Delamination}

The drilling parameters such as spindle speed and feed rate highly influence the cutting forces and delamination in the drilling of CFRP laminates. The cutting forces decrease with the higher cutting speed and increase with the increasing feed rate, drill size [19].[20] Had investigated the different factors affecting the delamination, the drill diameter is the cutting parameter which has greater influence on delamination (88.39\%) during drilling of CFRP composite materials. Babu and sunny [21] presented delamination study of composite materials by conducting drilling experiments using Taguchi's L25, 5-level orthogonal array; ANOVA was used to analyze the data obtained from the experiments and finally determine the optimal drilling parameters in drilling GFRP composite materials. Experiments conducted to determine whether varying feed and spindle speed during drilling could reduce the delamination. Wei Y [22] have conducted experiments on the carbon fibre reinforced plastic and $\mathrm{Ti}$ alloy stacks and reveals drilling forces increased with the elevation of feed rate, but had uncertain interactive relationships with cutting speed. Delamination area can reduced with lower feed rate and delamination will suddenly increase a lot after feed rate is over a critical value. Vijayan Krishnaraj [23] had reported an experimental investigation on thin CFRP using K20 carbide drill by varying various input parameters optimized using genetic algorithm. Achieved optimized values for spindle speed and feed rate are 12,000 rpm and 0.137 $\mathrm{mm} / \mathrm{rev}$ respectively. Sinan Al-wandi [24] experimental and simulation results indicated that thrust force and torque 
increased with the increase in feed rate and decreased with the increase in spindle speed. In addition, results showed delamination increases with the increase of feed rate and decreases with the spindle speed, as delamination increased drastically when feed rate is over $500 \mathrm{~mm} / \mathrm{min}$. In addition, presented results showed in the double point angle drill had less delamination than the twist drill. Y. Turkey [25] had performed the orthogonal machining operation on CFRP composite, the most damaged areas noticed at the hole exit since an impregnation problem has been encountered.

Table 1: Effect of Inputs on the Responses

\begin{tabular}{|c|l|l|l|}
\hline $\begin{array}{c}\text { Sl. } \\
\text { No }\end{array}$ & $\begin{array}{l}\text { Input Factor } \\
\text { Change }\end{array}$ & \multicolumn{1}{|c|}{ Effect on Response } & \multicolumn{1}{c|}{ Reason } \\
\hline 1 & $\begin{array}{l}\text { Increase in } \\
\text { Speed }\end{array}$ & $\begin{array}{l}\text { Thrust force and surface } \\
\text { roughness decreases. }\end{array}$ & $\begin{array}{l}\text { At higher spindle speeds the cutting tool rubs } \\
\text { around the hole wall more frequently causing higher } \\
\text { distortions which increase the circularity error [35, } \\
41,44,46] .\end{array}$ \\
\hline 2 & $\begin{array}{l}\text { Increase in } \\
\text { feed }\end{array}$ & $\begin{array}{l}\text { Thrust force and surface } \\
\text { roughness and damage } \\
\text { increases. }\end{array}$ & $\begin{array}{l}\text { At high feed, the tool enters the work faster, thus } \\
\text { increasing the thrust force. The faster entry of the } \\
\text { tool damages the inner surface decreases the surface } \\
\text { roughness [36,37,38] }\end{array}$ \\
\hline 3 & $\begin{array}{l}\text { Increase in } \\
\text { Point angle }\end{array}$ & $\begin{array}{l}\text { Thrust force and damage } \\
\text { increases. No clear trend } \\
\text { for Surface roughness }\end{array}$ & $\begin{array}{l}\text { At high point angles, the surface-to-surface contact } \\
\text { between the cutting edge and work increases. The } \\
\text { increase in thrust also increases the damage } \\
{[38,39,40,41]}\end{array}$ \\
\hline 4 & $\begin{array}{l}\text { Increase in } \\
\text { Tool diameter }\end{array}$ & $\begin{array}{l}\text { Thrust force increases. } \\
\text { No clear trend for } \\
\text { Surface roughness }\end{array}$ & $\begin{array}{l}\text { As diameter increases, the contact area of the tool } \\
\text { with the work increases and thus elevates the thrust } \\
\text { force [37,42,43,45] }\end{array}$ \\
\hline
\end{tabular}

\section{Effect of Drilling Factors on Thrust Force, Surface Roughness and Torque}

S D S [26] conducted experiments on the bi directional CFRP and optimized the process parameters with Taguchi method, $4 \mathrm{~mm}$ drill bit diameter and $1800 \mathrm{rpm}$ spindle speed shows the minimum thrust force and surface roughness. GongDong Wang [27] compared twist pilot hole and step-drill bit on influence of carbon fiber reinforcement polymer, conclude that conventional drilling by use of twist drill may not be the appropriate method to drill laminates as it records the highest thrust forces both at low and high feed rates. A. Caggiano[28] had presented the image analysis for the CFRP drilled hole arrangement. N. Feito[29] developed the numerical model to predict the thrust force response on the carbon wovenlaminates. A. N. AMIR [30] conducted several experiments on different tool geometry along with different speeds to observe the thrust force, Lowest thrust force obtained from experiment with full back support of $13.7 \mathrm{~N}$. Different design of back plates giving slightly different results for torque. Kumar D [31] did experimental investigation observed that the surface roughness at a feed rate of $0.10 \mathrm{~mm} / \mathrm{rev}$ was higher than that at a feed rate $0.02 \mathrm{~mm} / \mathrm{rev}$, using solid carbide eight-facet drill. QingxunMeng[11] had developed a new analytical model to predict the instantaneous thrust force of drilling the laminate composite materials which has different stack sequence. Y. Turki[25] performed orthogonal drilling on the carbon epoxy composite, the fiber orientation relative to the cutting speed direction is a key factor which determines the surface quality in drilling.

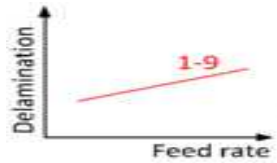

1 Davim et al. [51, 52, 53]

$2 \quad$ Kilickap [54]

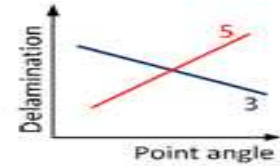

2.

4

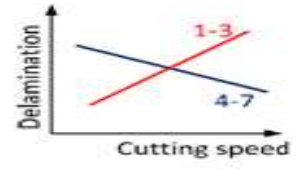

Rsardinas et al. [53]

Gaitonde et al. [55,56] 


$\begin{array}{llll}3 & \text { Rubio et al.[57] } & 6 & \text { Rawat et al [58] } \\ 4 & \text { Tsao et al.[59] } & 8 & \text { Arul st al.[60] }\end{array}$

Figure 4: Effects of Input Variables on Delamination when Drilling Composite Laminates

\section{Effect of Tool Geometry and Materials On Delamination, Thrust Force and Surface Roughness}

Drill geometry such as point angle and helix angle have high importance in effecting delamination when drilling CFRP; small point angle and low helix angle are preferred for good hole entrance [24]. Sinan Al-wandi [24] had compared twist drill and double point angle drill having same helix angle with different point angle, results showed that double point angle drill had less delamination than the twist drill. Jamel Saoudi[33] proposed realistic model to predict critical thrust force responsible for drilling-induced exit-ply delamination in a multi-directional carbon fibre-reinforced plastic laminate with core drill. [34] Presented the diamond drill provides slightly better results than the TiN/TiAlN drill. Kumar D [31] compared three drill bits HSS drill, solid carbide eight-facet drill and Carbide tipped straight shank (K20) drill on GFRP and recommendedsolid carbide eight-facet drill for drilling. [6] Analyzed the better surface finish is observed with SPUR drill with spindle speed of $6750 \mathrm{rpm}$ and a feed rate of $2025 \mathrm{~mm} / \mathrm{min}$.

\section{OPTIMIZATION OF DRILLING PROCESS PARAMETERS}

Selection of optimum parameters during machining the component is an important task for manufacturing industries. Machining under optimum conditions will eliminate unnecessary experimentation and reduces the labor and operating cost. Hence, in order to find out the optimum conditions, several studies made over a period. Shahrajabian H [47] optimized process parameters to achieve good surface finish with the good circularity of the hole at spindle speed of 4000 RPM, feed rate of $50 \mathrm{~mm} / \mathrm{min}$, and tool angle point of 100 degrees. Geier N [48] had optimized the cutting speed of 50 $(\mathrm{m} / \mathrm{min})$, feed rate of $0.049(\mathrm{~mm} / \mathrm{rev})$ and a screw pitch of the feeding helix of $3(\mathrm{~mm})$ produce good-quality holes with orbital drilling. Voss R [49] optimized values of High cutting velocities and feed rates in the range of vc $=200 \mathrm{~m} / \mathrm{min}$ and $\mathrm{f}=100 \mathrm{~mm} /$ rot generate better machining quality. Submitted H M A I [50] numerically optimized the process parameters on the conventional machining of GFRP.

Table 2: Optimum Conditions Explored from Previous Studies

\begin{tabular}{|c|c|c|c|c|}
\hline $\begin{array}{l}\text { Sl. } \\
\text { No }\end{array}$ & Authors & Responses Explored & Optimum Conditions & Ref. \\
\hline 1 & $\begin{array}{l}\text { Dhirajkumar } \\
\text { et. al }\end{array}$ & $\begin{array}{c}\text { Thrust Force, } \\
\text { Delamination, Surface } \\
\text { Roughness }\end{array}$ & $\begin{array}{c}\text { Speed }=2000 \mathrm{rpm} \text { Feed }=0.1 \mathrm{~mm} / \mathrm{rev} \text { and Solid } \\
\text { carbide drill bit }\end{array}$ & 61 \\
\hline 2 & $\begin{array}{l}\text { N. Geier } \\
\text { and T. } \\
\text { Szalay }\end{array}$ & $\begin{array}{c}\text { Cutting Force, } \\
\text { Delamination, Surface } \\
\text { Roughness }\end{array}$ & $\begin{array}{c}\text { speed }=50 \mathrm{~mm} / \mathrm{min}, \text { Feed }=0.049 \mathrm{~mm} / \mathrm{rev} \text { and } \\
\text { Screw pitch of feeding helix }=3 \mathrm{~mm}\end{array}$ & 62 \\
\hline 3 & D. S. S & $\begin{array}{l}\text { Thurst Force, Surface } \\
\text { Roughness }\end{array}$ & $\begin{array}{c}\text { Speed }=1800 \mathrm{rpm}, \text { Feed }=10 \mathrm{~mm} / \mathrm{min}, \text { Point angle }= \\
90^{\circ}, \text { Drill diameter }=4 \mathrm{~mm}\end{array}$ & 63 \\
\hline 4 & $\begin{array}{l}\text { K. Abhishek } \\
\text { et. al }\end{array}$ & $\begin{array}{c}\text { Thurst Force, } \\
\text { Delamination and Torque }\end{array}$ & $\begin{array}{c}\text { Speed }=2800 \mathrm{rpm}, \text { Feed }=50 \mathrm{~mm} / \mathrm{min}, \text { Drill diameter } \\
=5 \mathrm{~mm}\end{array}$ & 64 \\
\hline 5 & Feito et al. & Delamination & $\begin{array}{c}\text { Speed : } 25-100 \mathrm{~m} / \mathrm{min} \text {, feed : } 0.05 \mathrm{~mm} / \mathrm{rev} \text {, point } \\
\text { angle }: 90^{0}-108^{0}\end{array}$ & 65 \\
\hline 6 & $\begin{array}{l}\text { Faraz and } \\
\text { Biermann4 }\end{array}$ & $\begin{array}{l}\text { Thrust force and } \\
\text { delamination }\end{array}$ & $\begin{array}{c}\text { Speed }: 80 \mathrm{~m} / \mathrm{min} \\
\text { feed }: 0.35 \mathrm{~mm} / \mathrm{rev}\end{array}$ & 66 \\
\hline 7 & $\begin{array}{l}\text { V. N. } \\
\text { Gaitonde } \\
\text { et.al } \\
\end{array}$ & Delamination & $\begin{array}{l}\text { Speed: } 4000 \mathrm{rpm} \text { Feed: } 1000 \mathrm{~mm} / \mathrm{min} \text { Point angle: } \\
\qquad 85^{\circ}\end{array}$ & 67 \\
\hline
\end{tabular}




\begin{tabular}{|c|c|c|c|c|}
\hline \multicolumn{5}{|c|}{ Table 2: Contd., } \\
\hline 8 & $\begin{array}{c}\text { B. Latha et. } \\
\text { al }\end{array}$ & Delamination & $\begin{array}{c}\text { Speed:1500rpm Feed:50mm=min Drill } \\
\text { diameter:6mm }\end{array}$ & 68 \\
\hline
\end{tabular}

\section{CONCLUSIONS}

This review work on fiber reinforced polymer composites under the influential factor is effectively studied. From the above work, it is concluded follow

- The delamination factor on exit is more than the entry panel of drill bit. Because the compression action takes place between the fiber at entry level and bush out of fibers happened at exit level of drill bit. This deviation happed because of direction of cutting tool to work

- The delamination effect on FRP composites reduced by proper selection of parameters and its level.

- The selection of factor levels for machining plays an important role during machining and selection of optimum levels helps the manufacturing firms to choose the correct machining conditions.

- Selection of appropriate statistical tool is also very important during optimization. It is taken based on the available input and output factors for drilling.

- Therefore, in order to produce defect free holes and mechanical joining of composite structures, the process of drilling on CFRP composite laminates needs monitored with in-depth planned experimentations.

\section{REFERENCES}

1. ASM Handbook (2002). Volume: 21 composites (pp. 27-34, 940, 951). USA.

2. Pihtili, H., \&Tosun, N. (2002). Investigation of the wear behaviour of a glass-fibre reinforced composite and plain polyester resin. Composites Science and Technology, 62, 367-370.

3. D. Liu, Y. Tang, W. L. Cong, A review of mechanical drilling for composite laminates, Composite Structures 94 (2012) 12651279.

4. Hintze, W., Cordes, M. \&Koerkel, G., 2015. Influence of weave structure on delamination when milling CFRP. Journal of Materials Processing Technology 216, 199-205

5. Wern CW, Ramulu M, Schukla A. Investigation of stresses in the orthogonal cutting of fibre reinforced plastics. ExpMech ;36:33-41

6. Grilo T J, Paulo R M F, Silva C R M and Davim J P 2013 Experimental delamination analyses of CFRPs using different drill geometries Compos. Part B Eng.

7. Faraz A, Biermann D and Weinert K. Cutting edge rounding: an innovative tool wear criterion in drilling CFRP composite laminates. Int J Mach Tools Manuf 2009; 49: 1185-1196.

8. Tagliaferri V, Caprine G, Diterlizzi A. Effect of drilling parameters on the finish and mechanical properties of GFRP composites. Int J Mach Tools Manufact 1990;30(1):77-84.

9. Wong TL, Wu SM, Croy GM. An analysis of delamination in drilling composite material.14th National SAMPE Technology Conference, Atlanta; 1982. p. 471-83. 
10. Seif MA, Khashaba UA, Rojas-Oviedo R. Measuring delamination in carbon epoxy composites using shadow Moire laser based imaging technique. Compos Struct 2007; 79; 113

11. C. C. Tsao, H. Hocheng, Y. C. Chen, Delamination reduction in drilling composite materials by active backup force, CIRP Annals - Manufacturing Technology 61 (2012) 91-94.

12. Isik B, Ekici E. Experimental investigations of damage analysis in drilling of woven glass fiber-reinforced plastic composites. Int JAdvManufTechnol 2010:861-9.

13. Ma FJ, Zhu XL, Kang RK, Dong ZG, Zou SQ. Study on the subsurface damages of glass fiberreinforced composites. Adv Mater Res 2013; 797:691-5.

14. Zhang H, Chen $W$, Chen D, Zhang L. Assessment of the exit defects in carbon fiber reinforced plastic plates caused by drilling. Key Eng Mater 2001; 196:43-52.

15. Konig, W., Wulf, Ch., Grab, P. and Willerscheid, H. (1985) 'Machining of fibre reinforced plastics', Annals of the CIRP, Vol. 34, No. 2, pp.537-548.

16. Davim J, Campos Rubio J, Abrao A. A novel approach based on digital image analysis to evaluate the delamination factor after drilling composite laminates. Composites Science and Technology 2007;67(9):1939-1945

17. Hocheng H, Tsao CC. The path towards delamination free drilling of composite materials. J Mater Process Technol 2005; 167:251-64

18. Wang GD, Li N, Xiong XH, et al. 3D level comprehensive evaluation of hole quality in drilling carbon fibre-reinforced plastics. Int J AdvManufTechnol 2017.

19. $D R, P R$, Jenarthanan M P and C S N 2017 Experimental investigation and analysis of factors influencing delamination and thrust force during drilling of carbon-fibre reinforced polymer composites Pigment Resin Technol.46 507-24

20. Ramirez C, Poulachon G, Rossi F, M'Saoubi R. Tool wear monitoring and hole surface quality during CFRP drilling. Proc CIRP 2014;13:163-8.

21. Babu J, Sunny T (2013) Optimization of process parameters in drilling of GFRP composites drilled by an end mill, International Journal of Recent Development in Engineering and Technology, 1(1): 16-23.

22. Wei $Y$, An $Q$, Ming $W$ and Chen M 2016 Effect of drilling parameters and tool geometry on drilling performance in drilling carbon fibre-reinforced plastic/titanium alloy stacks Adv. Mech. Eng.

23. Krishnaraj V, Prabukarthi A, Ramanathan A, Elanghovan N, Kumar M S, Zitoune R and Davim J P 2012 Optimization of machining parameters at high speed drilling of carbon fibre reinforced plastic (CFRP) laminates Compos. Part B Eng.43 $1791-9$

24. Al-wandi S, Ding S and Mo J 2017 An approach to evaluate delamination factor when drilling carbon fibre-reinforced plastics using different drill geometries: experiment and finite element study Int. J. Adv. Manuf. Technol. 1-19

25. Turki Y, Habak M, Velasco R and Vantomme P 2017 Highlighting cutting mechanisms encountered in carbon/epoxy composite drilling using orthogonal cutting Int. J. Adv. Manuf. Technol.92 685-97

26. S D S 2017 Characterization of Machining Parameters on Thrust Force and Surface Roughness in Drilling of 40-60 Wt. \% BD CFRP Composite 12 5570-7

27. Wang G-D and Kirwa M S 2017 Comparisons of the use of twist, pilot-hole and step-drill on influence of carbon fiberreinforced polymer drilling hole quality 
28. Caggiano A, Angelone R and Teti R 2017 Image Analysis for CFRP Drilled Hole Quality Assessment Procedia CIRP62 440-5

29. Feito N, Diaz-Álvarez J, López-Puente J and Miguelez, M H 2016 Numerical analysis of the influence of tool wear and special cutting geometry when drilling woven CFRPs Compos. Struct.138 285-94

30. Amir A N, Ye L and Chang L 2016 Drilling Conditions on Hole Quality for CFRP Laminates Am. Soc. Compos. Thirty-First Tech. Conf.

31. Kumar D, Singh K K and Zitoune $R 2016$ Experimental investigation of delamination and surface roughness in the drilling of GFRP composite material with different drills Adv. Manuf. Polym. Compos. Sci.2 47-56

32. Meng Q, Zhang K, Cheng H, Liu S and Jiang S 2015 An analytical method for predicting the fluctuation of thrust force during drilling of unidirectional carbon fiber reinforced plastics J. Compos. Mater. 49 699-71

33. Saoudi J, Zitoune R, Gururaja S, Salem M and Mezleni S 2017 Analytical and experimental investigation of the delamination during drilling of composite structures with core drill made of diamond grits: X-ray tomography analysis J. Compos. Mater. 2199831772459

34. Pinho L V, Carou D and Davim J P 2016 Delamination of carbon fiber reinforced plastics: Analysis of the drilling method Indian J. Eng. Mater. Sci.23 134-8

35. R. Vinayagamoorthy Parametric Optimization Studies on Drilling of Sandwich Composites Using Box-Behnken Design 1-35

36. Prakash $M$ and Dileep Aditya Dhar P 2017 Investigation on the effect of drilling parameters on the tool wear and delamination of glass fibre-reinforced polymer composite using vibration signal analysis J. Compos. Mater. 2199831772810

37. Vinayagamoorthy $R 2017$ A review on the machining of fiber-reinforced polymeric laminates J. Reinf. Plast. Compos. 73168441773153

38. Voss R, Seeholzer L, Kuster F and Wegener K 2017 Cutting Process Tribometer Experiments for Evaluation of Friction Coefficient Close to a CFRP Machining Operation Procedia CIRP66 204-9

39. Giasin K and Ayvar-Soberanis $S 2017$ An Investigation of burrs, chip formation, hole size, circularity and delamination during drilling operation of GLARE using ANOVA Compos. Struct.159 745-60

40. Pascual V, San-Juan M, Santos F J, Martín Ó and de Tiedra M P 2017 Study of axial cutting forces and delamination phenomenon in drilling of carbon fiber composites Procedia Manuf.13 67-72

41. Melentiev R, Priarone P C, Robiglio M and Settineri L 2016 Effects of Tool Geometry and Process Parameters on Delamination in CFRP Drilling: An Overview Procedia CIRP45 31-4

42. Zitoune R, Krishnaraj V, Collombet $F$ and Le Roux S 2016 Experimental and numerical analysis on drilling of carbon fibre reinforced plastic and aluminium stacks Compos. Struct.146

43. Jia Z, Fu R, Niu B, Qian B, Bai Y and Wang F 2016 Novel drill structure for damage reduction in drilling CFRP composites Int. J. Mach. Tools Manuf.110 55-65

44. Abhishek K, Datta S and Mahapatra S S 2016 Multi-objective optimization in drilling of CFRP (polyester) composites: Application of a fuzzy embedded harmony search (HS) algorithm Meas. J. Int. Meas. Confed.77 222-39

45. Bonnet C, Poulachon G, Rech J, Girard Y and Costes J P 2015 CFRP drilling: Fundamental study of local feed force and consequences on hole exit damage. Int. J. Mach. Tools Manuf.94 57-64

46. Kavad B V, Pandey A B, Tadavi M V and Jakharia H C 2014 A Review Paper on Effects of Drilling on Glass Fiber Reinforced Plastic Procedia Technol.14 457-64 
47. Shahrajabian H and Farahnakian M 2013 Modeling and multi-constrained optimization in drilling process of carbon fiber reinforced epoxy composite Int. J. Precis. Eng. Manuf.14 1829-37

48. Geier N and Szalay T 2017 Optimisation of process parameters for the orbital and conventional drilling of uni-directional carbon fibre-reinforced polymers (UD-CFRP) Meas. J. Int. Meas. Confed.110 319-34

49. Voss R, Seeholzer L, Kuster F and Wegener K 2017 Influence of fibre orientation, tool geometry and process parameters on surface quality in milling of CFRP CIRP J. Manuf. Sci. Technol.18 75-91

50. Submitted H M A I 2013 Numerical optimization for cutting process in glass fiber reinforced plastic using conventional and non-conventional methods 199

51. Davim JP, Reis P. Drilling carbon fiber reinforced plastics manufactured by autoclave experimental and statistical study. Mater Des 2003;24:315-24.

52. Davim JP, Reis Pedro. Study of delamination in drilling carbon fiber reinforced plastic (CFRP) using design experiments. Compos Struct 2003;59:481-7.

53. Sardinas $R Q$, Reis $P$, Davim JP. Multi-objective optimization of cutting parameters for drilling laminate composite materials by using genetic algorithms. Compos Sci Technol 2006;66:3083-8.

54. Kilickap E. Optimization of cutting parameters on delamination based on Taguchi method during drilling of GFRP composite. Expert Syst Appli 2010;37:6116-22

55. Gaitonde vVN, Karnik SR, Campos Rubio J, Esteves Correia A, Abrao AM, Paulo Davim J. Analysis of parametric influence on delamination in high-speed drilling of carbon fiber reinforced plastic composites. J Mater Process Technol 2008;203:4318.

56. Karnik SR, Gaitonde VN, Campos Rubio J, Esteves Correia A, Abrao AM, Davim JP. Delamination analysis in high speed drilling of carbon fiber reinforced plastics (CFRP) using artificial neural network model. Mater Des 2008;29:1768-76

57. Rubio JC, Abrao AM, Faria PE, Correia AE, Davim JP. Effects of high speed in the drilling of glass fibre reinforced plastic: evaluation of delamination factor. Int J Mach Tools Manuf 2008;48:715-20.

58. Rawat S, Attia H. Characterization of the dry high speed drilling process of woven composites using machinability maps approach. CIRP Annals - Manuf Technol 2009;58:105 8.

59. Tsao CC, Hocheng H. Computerized tomography and C-Scan for measuring delamination in the drilling of composite materials using various drills. Int J Mach Tools Manuf 2005;45:1282-7

60. Arul S, Vijayaraghavan L, Malhotra SK, Krishnamurthy R. The effect of vibratory drilling on hole quality in polymeric composites. Int J Mach Tools Manuf 2006;46:252-9

61. D. Kumar and K. K. Sing, "Experimental analysis of Delamination, Thrust Force and Surface roughness on Drilling of Glass Fibre Reinforced Polymer Composites Material Using Different Drills,” Mater. Today Proc., vol. 4, no. 8, pp. 7618-7627, 2017.

62. N. Geier and T. Szalay, "Optimisation of process parameters for the orbital and conventional drilling of uni-directional carbon fibre-reinforced polymers (UD-CFRP)," Meas. J. Int. Meas. Confed., vol. 110, pp. 319-334, 2017.

63. D. S. S, “Characterization of Machining Parameters on Thrust Force and Surface Roughness in Drilling of 40-60 Wt. \% BD CFRP Composite," vol. 12, no. 16, pp. 5570-5577, 2017. 
64. K. Abhishek, S. Datta, and S. S. Mahapatra, "Multi-objective optimization in drilling of CFRP (polyester) composites: Application of a fuzzy embedded harmony search (HS) algorithm,” Meas. J. Int. Meas. Confed., vol. 77, pp. 222-239, 2016.

65. Ameur MF, Habak M, Kenane M, et al. Machinability analysis of dry drilling of carbon/epoxy composites: cases of exit delamination and cylindricity error. Int J Adv Manuf Technol 2017; 88: 2557-2571

66. Faraz A and Biermann D. Subsequent drilling on pilot holes in woven carbon fibre reinforced plastic epoxy laminates: the effect of drill chisel edge on delamination. Proc IMechE, Part B: J Eng Manuf 2011; 225: 1493-1504

67. V. N. Gaitonde, S. R. Karnik, J. C. Rubio, a. E. Correia, a. M. Abrao, and J. P. Davim, "A study aimed at minimizing delamination during drilling of CFRP composites,” J. Compos. Mater., vol. 45, no. 22, pp. 2359-2368, 2011.

68. B. Latha, V. S. Senthilkumar, and K. Palanikumar, "Modeling and optimization of process parameters for delamination in drilling glass fiber reinforced plastic (GFRP) composites,” Mach. Sci. Technol., vol. 15, no. 2, pp. 172-191, 2011. 